\title{
Hidrogeoquímica das águas minerais envasadas do Brasil
}

\author{
Reginaldo Bertolo ${ }^{1}$, Ricardo Hirata ${ }^{2}$ \& Amélia Fernandes $^{3}$
}

\begin{abstract}
Resumo Análises químicas provenientes de trezentas e três marcas de águas minerais envasadas brasileiras foram reunidas e interpretadas em sua hidrogeoquímica. Este universo representa quase $50 \%$ das 672 concessões de lavra válidas no país. Estas águas minerais são, em geral, de baixa mineralização $(\mathrm{RS}<100 \mathrm{mg} / \mathrm{L})$ e de baixo $\mathrm{pH}(\approx 6,0)$, fazendo parte de sistemas de fluxos de natureza predominantemente rasa $(<70 \mathrm{~m})$ e de curto tempo de trânsito no aqüífero. Neste contexto, destacam-se as águas das regiões central e norte do país, que são de baixíssima mineralização ( $\mathrm{RS}<30 \mathrm{mg} / \mathrm{L}$ ). A dissolução de minerais aluminossilicatos e/ou carbonáticos e, secundariamente, a contribuição de sódio e cloreto em sprays marinhos nas regiões costeiras, são os principais fenômenos geoquímicos observados que determinam os tipos e as proporções dos íons na água. Já a quantidade de íons é definida principalmente pelas profundidades de circulação da água subterrânea. Os dados hidroquímicos indicam que cerca de 1/3 das águas minerais brasileiras situam-se em contexto aqüífero de elevada vulnerabilidade natural à contaminação, e que $1 / 4$ dessas águas, embora quimicamente potáveis, apresentam algum sinal de alteração na composição química ocasionada por atividade antrópica, como indicada pela ocorrência notável do íon nitrato (de 3 a 49 mg/L).
\end{abstract}

Palavras chave: Água mineral, hidrogeoquímica. água subterrânea.

\begin{abstract}
Hydrogeochemistry of the bottled mineral waters in Brazil. Three hundred and three labels of bottled mineral water from different sources were collected and analyzed in terms of their hydrogeochemistry. This total represents almost $50 \%$ of the 672 sources in operation in the country. In general, Brazilian mineral waters are of low mineralization (TDS $<100 \mathrm{mg} / \mathrm{L}$ ) and $\mathrm{pH}$ around 6,0 , denoting groundwater flow in rapid and shallow systems $(<70 \mathrm{~m})$. Waters in the central and northern regions of the country deserve special mention, once they show an extremely low degree of mineralization ( $\mathrm{RS}<30 \mathrm{mg} / \mathrm{L}$ ). The main geochemical phenomena determining type and proportion of dissolved species include dissolution of aluminosilicates and/ or carbonates and, secondarily, sodium and chloride contributions associated with marine sprays in coastal regions. On the other hand, the quantity of dissolved species is mainly governed by depth of groundwater circulation. Almost $1 / 3$ of Brazilian mineral waters occur in aquifers with intrinsic high vulnerable to contamination. Furthermore, 1/4 of these mineral waters, although potable, already show some signs of anthropic impact, as indicated by the notable occurrence of nitrate ions (from 3 to $49 \mathrm{mg} / \mathrm{L}$ ).
\end{abstract}

Keywords: mineral water, hydrogeochemistry, groundwater.

\begin{abstract}
APRESENTAÇÃO Este trabalho objetivou descrever as características químicas gerais de uma parcela significativa da população das águas minerais envasadas brasileiras e fornecer uma visão geral dos fatores e processos geoquímicos que atuam na composição química destas águas. Ainda com base nas suas características químicas, procurou-se também avaliar aspectos de qualidade, vulnerabilidade de aqüíferos e sinais de contaminação originados por fontes antrópicas.

As principais fontes de informações foram os dados de análises químicas constantes em 303 rótulos de água mineral obtidos no mercado brasileiro e provenientes de todas as regiões do país. Esta avaliação limitou-se, portanto, àquelas águas destinadas ao consumo alimentício, não tendo sido consideradas as águas provenientes de balneários localizados em estâncias hidrominerais, muitas das quais utilizadas para fins terapêuticos e contendo composição química muito
\end{abstract}

diferenciada. Além disto, as interpretações dos fenômenos hidrogeoquímicos foram muitas vezes baseadas em aspectos gerais do conjunto das águas, sendo que os casos específicos necessitam de uma abordagem mais aprofundada.

Com base nas informações coletadas, comprovou-se que a composição química da água mineral é o resultado final de uma série de fatores relacionados com o clima, a distância dos oceanos, o tipo de rocha que ela atravessa, a profundidade de circulação no aqüífero e também a eventual atuação de contaminação de origem antrópica. Os itens a seguir apresentam uma avaliação de cada uma destas variáveis na composição química da água mineral.

MÉTODO Foram obtidos rótulos de água mineral provenientes de todas as partes do Brasil. Complementarmente, dados de análises químicas foram também 
obtidos em Martins et al. (2002), no site SIGHIDRO (DNPM 2005), nos sites de empresas de água mineral na internet, e a partir de relatórios técnicos, totalizando 375 análises químicas de águas minerais comercializadas no país.

Estes dados foram informatizados e selecionados segundo os critérios de: (1) escolha da análise mais recente, caso houvesse mais que uma análise da mesma fonte; (2) erro inferior a 5\% de balanço iônico; e (3) coerência entre os valores de $\mathrm{pH}$ e as concentrações das espécies $\mathrm{HCO}_{3}^{-}$e $\mathrm{CO}_{3}^{-2}$. O processo de seleção resultou em uma população de 303 análises, que é representativa em relação ao total de 672 concessões de lavra distribuídas no Brasil (Queiroz 2004). Da população considerada, um grupo de 39 análises contendo concentrações de nitrato superiores a $5 \mathrm{mg} / \mathrm{L}$ foi separado e tratado a parte, por se considerar que se trata de águas com influência antrópica em sua composição.

As fontes de água mineral foram locadas em diversos mapas geológicos, com escalas variando de 1:50.000 a 1:1.000.000, de onde foram obtidas informações sobre a estratigrafia, tipos de rochas aflorantes e mineralogia, permitindo correlacionar a composição química da água percolante e a rocha hospedeira. Determinou-se, também, o contexto macro-hidrogeológico das fontes através do Mapa Hidrogeológico do Brasil (DNPM 1983) e o contexto macro-climático, através do Mapa de Climas do Brasil (IBGE 2002).

As análises foram agrupadas em função do contexto hidrogeológico para identificar os processos hi- droquímicos atuantes nas águas minerais. $\mathrm{Na}$ situação de existência de várias análises para um mesmo contexto hidrogeológico, um valor médio e o desvio padrão foram calculados. Índices geoquímicos baseados em Hounslow (1995) foram obtidos, assim como diagramas de estabilidade de aluminossilicatos. Estatísticas, cálculo de índices de saturação de minerais e diagramas de Piper foram realizados com o programa Hydrowin 3.0 (Calmbach, 1995).

Em várias das análises, as concentrações dos solutos encontravam-se expressas em massa de sais por litro. Estas foram transformadas em concentrações de espécies iônicas dissolvidas, através de cálculos de proporcionalidade, considerando as massas iônicas e moleculares.

Informações sobre o conteúdo de sílica dissolvida foram obtidas em apenas 130 análises. Para se elevar o número dessas informações, as concentrações de sílica dissolvida foram também calculadas para outras 53 análises de acordo com a Equação 1 (Hounslow 1995). Esta equação foi utilizada nas ocasiões em que os valores de resíduo seco (RS) guardavam correlação adequada com os valores de condutividade elétrica e com as concentrações parciais das espécies dissolvidas. Outras 117 amostras não tiveram disponíveis informações sobre conteúdo de sílica dissolvida.

$\left[\mathrm{SiO}_{2}\right]=\mathrm{RS}-\left(\Sigma_{\text {cátions }}+\Sigma_{\text {anions }}\right)+0,5082 *\left[\mathrm{HCO}_{3}^{-}+\mathrm{CO}_{3}^{-2}\right]$

onde: $\mathrm{RS}=$ resíduo seco $(\mathrm{em} \mathrm{mg} / \mathrm{L})$

Tabela 1 - Média de alguns parâmetros fisico-químicos em função da classificação climática.

\begin{tabular}{|c|c|c|c|c|}
\hline Região/Estado & Clima & $\mathrm{N}^{\circ}$ Dados & Temp. $\left({ }^{\circ} \mathrm{C}\right)$ & Res.Seco. $(\mathrm{mg} / \mathrm{L})$ \\
\hline \multirow{2}{*}{$\mathrm{CE}$} & Quente semi-árido & 5 & 27,14 & 99,64 \\
\hline & $T_{a r}>18^{\circ} \mathrm{C} ;$ estiagem $>6$ meses & $D P=$ desv.pad & 2,79 & 46,04 \\
\hline \multirow{2}{*}{$\begin{array}{l}\text { Centro-Oeste, } \\
\text { CE e RN }\end{array}$} & Quente semi-úmido & 38 & 26,36 & 82,07 \\
\hline & $T_{a r}>18^{\circ} \mathrm{C} ; 4$ meses secos & $D P$ & 2,94 & 116,23 \\
\hline \multirow{2}{*}{$\begin{array}{l}\text { Norte, Nordeste } \\
\text { e RJ }\end{array}$} & Quente úmido & 63 & 25,74 & 61,09 \\
\hline & $T_{a r}>18^{\circ} \mathrm{C} ; 2$ meses secos & $D P$ & 1,87 & 62,32 \\
\hline \multirow{2}{*}{ SP, RJ } & Subquente úmido & 36 & 22,54 & 73,28 \\
\hline & $15<T_{a r}<18^{\circ} \mathrm{C} ; 2$ meses secos & $D P$ & 2,63 & 57,29 \\
\hline \multirow{2}{*}{ MG } & Subquente semi-úmido & 14 & 22,22 & 72,49 \\
\hline & $15<T_{a r}<18^{\circ} \mathrm{C} ; 4$ meses secos & $D P$ & 2,11 & 85,82 \\
\hline \multirow{2}{*}{ SP, MG } & Mesotérmico úmido & 83 & 20,82 & 82,79 \\
\hline & $10<T_{a r}<15^{\circ} \mathrm{C} ; 2$ meses secos & $D P$ & 1,54 & 73,81 \\
\hline \multirow{2}{*}{ RS, SC, PR } & Mesotérmico super-úmido & 25 & 20,55 & 130,59 \\
\hline & $10<T_{a r}<15^{\circ} \mathrm{C} ; \mathrm{sem} \mathrm{seca}$ & $D P$ & 1,85 & 72,66 \\
\hline
\end{tabular}


INFLUÊNCIA DO CLIMA E DO MAR O IBGE (2002) classifica o clima do Brasil de acordo com a temperatura média anual do ar e em função do número de meses de estiagem. A tabela 1 resume as informações climáticas por região do território brasileiro. Esta tabela também apresenta dados estatísticos de temperatura e resíduo seco (RS) das águas em função do clima. Observa-se que existe correlação entre as temperaturas do ar e da água, já que há um aumento da temperatura da água dos climas mais frios $\left(20,5^{\circ} \mathrm{C}\right.$, Sul $)$ para os mais quentes $\left(26-27^{\circ} \mathrm{C}\right.$, Norte/Nordeste), observação coerente com o apresentado em Szikszay (1993).

Nota-se, ainda, não haver uma clara associação entre quantidade de sólidos dissolvidos e a classificação climática utilizada do ponto de vista da umidade. As razões para a ausência de correlação entre o RS e o clima são: (1) a quantidade de sólidos dissolvidos é mais dependente da relação da água com a rocha e da profundidade de circulação da água do que com aspectos climáticos; e (2) a classificação climática adotada não leva em consideração a quantidade de precipitação, mas somente o número de meses de estiagem.

A influência do mar é notada mais intensamente com relação às concentrações de cloreto em localidades situadas próximas ao mar, que tendem a ser mais elevadas por influência das concentrações deste íon na água do mar, que é transportado para as áreas continentais juntamente com a umidade marinha, tal como também anotado em Szikszay (1993). A concentração média de cloreto obtida de fontes situadas em cidades litorâneas brasileiras é de 14,99 mg/L, enquanto que esta média é de $2,33 \mathrm{mg} / \mathrm{L}$ nas demais localidades brasileiras, excetuando-se aquelas situadas em clima semi-árido.

INFLUÊNCIA DA PROFUNDIDADE DE CIRCULAÇÃO DA ÁGUA SUBTERRÂNEA A acidez da solução de percolação que adentra o solo relaciona-se com o ácido carbônico $\left(\mathrm{H}_{2} \mathrm{CO}_{3}\right)$, produzido pela dissolução do gás carbônico $\left(\mathrm{CO}_{2}\right)$ na água e originado principalmente pela degradação da matéria orgânica do solo e pela respiração de raízes. Na medida em que a água subterrânea se move ao longo de sua linha de fluxo no aqüífero, espera-se que a acidez seja consumida pelas reações de intemperismo químico e que haja um aumento na quantidade de sólidos dissolvidos na solução de lixiviação (Freeze \& Cherry 1979). De uma forma geral, portanto, espera-se que a água subterrânea de sistemas de fluxos rasos e de rápido tempo de trânsito no aqüífero seja mais ácida e com menor quantidade de sólidos dissolvidos, ao passo que a água que possui $\mathrm{pH}$ mais elevado e maior quantidade de sólidos dissolvidos seja típica de sistemas de circulação mais profunda, de menor velocidade e de maior tempo de trânsito.

A figura 1 apresenta a correlação entre os valores de $\mathrm{pH}$ e resíduo seco (RS) das águas minerais. Não foram considerados neste gráfico os dados das águas com conteúdo de nitrato maior que $5 \mathrm{mg} / \mathrm{L}$ (39 amostras), devido à influência humana nas concentrações, e das águas carbogasosas (13 amostras), por produzirem águas ácidas com quantidades relativamente mais elevadas de RS.

Observa-se que a correlação positiva entre $\mathrm{pH}$ e RS é coerente com o modelo citado e possibilita identificar populações de águas que são representativas de fluxos rasos e de fluxos mais profundos. Cerca de $1 / 3$ das águas minerais brasileiras pode ser classificada como de baixíssima mineralização, apresentando características de $\mathrm{pH}<6,0$ e $\mathrm{RS}<50 \mathrm{mg} / \mathrm{L}$. Estas características são indicativas de que os aqüíferos explorados fornecem água de circulação local, rasa e de curto tempo de trânsito, sendo, portanto, vulneráveis à poluição. Águas com essas características ocorrem principalmente nas regiões Norte, Nordeste e Centro-Oeste, mas também são comuns no Sudeste e Sul do país. Algumas dessas águas possuem composição semelhante à de uma chuva genérica, com $\mathrm{RS} \approx 5 \mathrm{mg} / \mathrm{L}$ e $\mathrm{pH}<5$. Apenas $4,5 \%$ da população representa águas com $\mathrm{pH}>7,0$ e RS $>200 \mathrm{mg} / \mathrm{L}$, típicas de sistemas de circulação mais profunda.

A forma de captação da água mineral é também um fator que condiciona a qualidade química da água.



Figura 1 - Correlação entre pH e resíduo seco das águas minerais (total 251 amostras) 


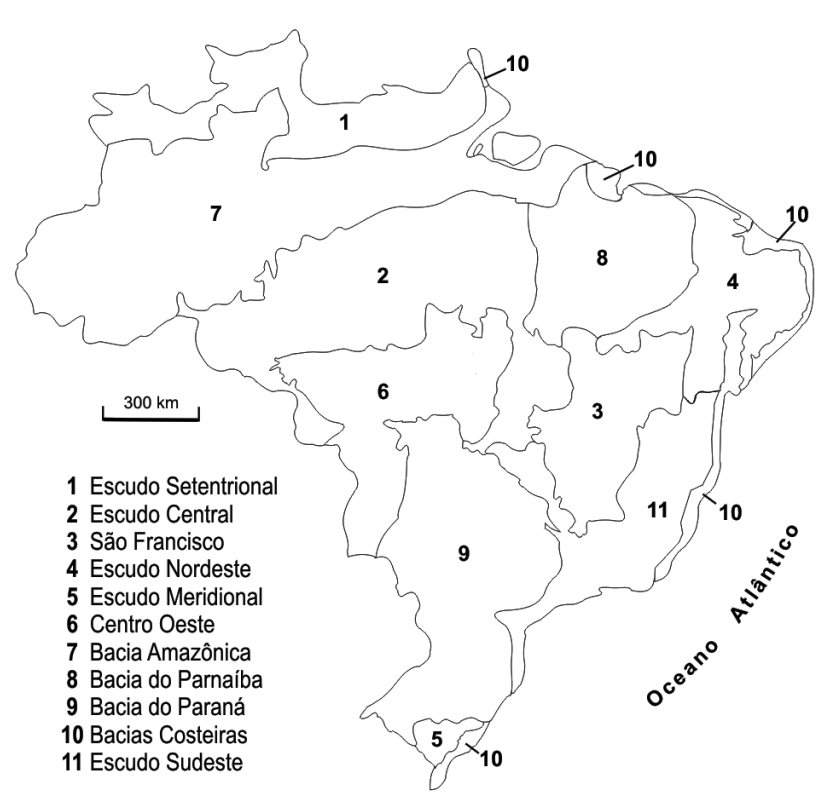

Figura 2 - Províncias Hidrogeológicas do Brasil (modificado de DNPM/CPRM - 1983).

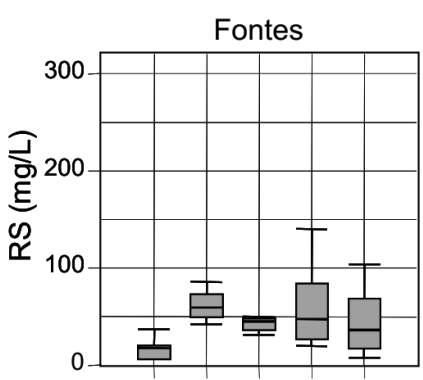

BA BC EN ES BP


Figura 3 - Faixas de valores de resíduo seco (RS) e de $\mathrm{pH}$ de águas provenientes de diferentes províncias hidrogeológicas e captadas por poços tubulares profundos e por caixas de captação

Águas captadas de poços tubulares profundos, onde as entradas de água se dão normalmente em maiores profundidade $(>70 \mathrm{~m})$, tendem a exibir valores de RS e pH mais elevados que as águas de fontes surgentes extra- ídas em caixas de captação. Considerando a compartimentação das grandes províncias hidrogeológicas do Brasil (DNPM/CPRM 1983) (Fig. 2), exemplos desta situação são apresentados na figura 3 .

Os valores de $\mathrm{pH}$ e resíduo seco (RS) das águas provenientes de fontes são menores que os das águas de poços profundos, comprovando a tendência de que as fontes em geral captam água de fluxos rasos em todos os contextos hidrogeológicos. Os valores médios de RS das águas captadas por poços no Escudo Sudeste e Bacia do Paraná tendem a ser o dobro dos valores médios das águas captadas por caixas de captação. As águas dos poços tendem a exibir valores de $\mathrm{pH}$ uma unidade acima daquelas águas provenientes de caixas de captação em todos os contextos hidrogeológicos.

Ainda na figura 3, nota-se que as maiores variações dos valores de $\mathrm{pH}$ e $\mathrm{RS}$ ocorrem nas águas das províncias do Escudo Sudeste e Bacia do Paraná. Tais variações devem estar associadas à possibilidade de haver fontes surgentes drenando fluxos profundos e poços profundos contendo filtros em profundidades rasas.

INFLUÊNCIA DA RELAÇÃO ÁGUA-ROCHA A interação química da água de percolação com os minerais da rocha hospedeira é o fator mais influente para a ocorrência dos diferentes tipos de espécies químicas na água subterrânea. Os subitens a seguir descrevem os principais processos hidrogeoquímicos atuantes nas águas minerais envasadas em função dos grupos de rochas que ocorrem nas grandes províncias hidrogeológicas do Brasil (Fig. 2).

A tabela 2 apresenta uma síntese da composição química dos principais grupos de água mineral provenientes de diferentes contextos geológicos. $\mathrm{Na}$ situação de existência de várias análises para um mesmo contexto geológico, um valor médio e o desvio padrão foram calculados. Quando da existência de poucas análises químicas para o contexto geológico, apenas uma amostra com análises químicas completas foi tomada como exemplo. As informações de concentrações de sílica das análises individuais nesta tabela correspondem a dados existentes.

A figura 4 apresenta a estatística dos grupos de análises, de onde se observa as diferentes famílias de águas. Os diagramas de Piper da figura 5 foram construídos considerando-se a totalidade da população de dados, sendo que algumas das análises da tabela 2 são identificadas na figura. A figura 6 apresenta diagramas de estabilidade de aluminossilicatos para os grupos de águas identificados na tabela 2. Os pontos relacionados com os valores médios de grupos de análises podem apresentar localização imprecisa devido às análises de sílica que (1) ou se encontravam indisponíveis em várias análises, ou (2) foram calculadas em parte das amostras.

A tabela 3 apresenta algumas relações iônicas e índices de saturação de alguns minerais reativos calculados com base nos resultados dos grupos de águas minerais identificados na tabela 2. A tabela 4 apresenta uma descrição sucinta das rochas e minerais encontra- 
Tabela 2 - Dados hidrogeoquimicos representativos de alguns contextos aqüiferos ou de algumas fontes selecionadas (em $\mathrm{mg} / \mathrm{L}$, exceto temp. e $\mathrm{pH}$ ).

\begin{tabular}{|c|c|c|c|c|c|c|c|c|c|c|c|c|c|c|}
\hline & $\mathrm{N}^{\circ}$ & & $\mathrm{T}\left({ }^{\circ} \mathrm{C}\right)$ & $\mathrm{pH}$ & RS & $\mathrm{Na}^{+}$ & $\mathrm{K}^{+}$ & $\mathrm{Ca}^{+2}$ & $\mathrm{Mg}^{+2}$ & $\mathrm{HCO}_{3}^{-}$ & $\mathrm{CO}_{3}^{-2}$ & $\mathrm{SO}_{4}^{-2}$ & $\mathrm{Cl}^{-}$ & $\mathrm{SiO}_{2}$ \\
\hline \multirow{2}{*}{$\begin{array}{l}\text { Bacia } \\
\text { Amazô- } \\
\text { nica }\end{array}$} & \multirow[t]{2}{*}{1} & $\begin{array}{l}\text { Sedimentos Cenozóicos - } \\
\text { Média } 11 \text { valores }\end{array}$ & 26,4 & 4,66 & 20,25 & 1,81 & 0,68 & 0,67 & 0,45 & 4,34 & & 0,79 & 1,41 & 7,11 \\
\hline & & Desvio padrão & 0,8 & 0,54 & 12,33 & 1,36 & 0,48 & 0,95 & 0,77 & 6,32 & & 1,39 & 1,16 & 5,61 \\
\hline \multirow{2}{*}{$\begin{array}{l}\text { Escudo } \\
\text { Central }\end{array}$} & \multirow[t]{2}{*}{2} & $\begin{array}{l}\text { Rochas ígneas e metamórficas } \\
\text { intemperizadas - Média 11valor. }\end{array}$ & 25,5 & 4,90 & 9,47 & 0,61 & 0,41 & 0,36 & 0,15 & 3,18 & & 0,03 & 0,21 & 4,86 \\
\hline & & Desvio padrão & 4,5 & 0,65 & 5,75 & 0,50 & 0,52 & 0,42 & 0,17 & 2,75 & & 0,06 & 0,23 & 3,04 \\
\hline $\begin{array}{l}\text { São } \\
\text { Francisco }\end{array}$ & 3 & $\begin{array}{l}\text { Grupo Bambuí - } \\
\text { Brasília DF }\end{array}$ & 26,0 & 6,6 & 47,1 & 7,01 & 0,8 & 6,41 & 2,31 & 46,0 & & 3,91 & 0 & 9,12 \\
\hline \multirow{3}{*}{$\begin{array}{l}\text { Bacias } \\
\text { Costeiras }\end{array}$} & \multirow[t]{2}{*}{4} & $\begin{array}{l}\text { Sedimentos - Tipo } 1 \text { - } \\
\text { média } 25 \text { valores }\end{array}$ & 27,8 & 4,86 & 46,68 & 8,31 & 2,74 & 0,88 & 1,00 & 7,73 & & 2,89 & 12,07 & 14,81 \\
\hline & & Desvio padrão & 2,02 & 0,48 & 20,98 & 4,55 & 3,29 & 0,72 & 0,48 & 4,44 & & 3,50 & 7,11 & 6,73 \\
\hline & 5 & $\begin{array}{l}\text { Sedimentos - Tipo } 2 \text { - } \\
\text { Aquiraz CE }\end{array}$ & 30,2 & 8,24 & 306,9 & 86,41 & 6,02 & 3,54 & 2,99 & 151,54 & & 39,6 & 26,58 & 30,11 \\
\hline $\begin{array}{l}\text { Bacia } \\
\text { Parnaíba }\end{array}$ & 6 & $\begin{array}{l}\text { Fm. Pedra de Fogo - } \\
\text { Teresina PI }\end{array}$ & 33,0 & 8,20 & 295,0 & 107,1 & 0 & 5,71 & 1,5 & 267,7 & & 9,95 & 13,16 & 31,58 \\
\hline \multirow{3}{*}{$\begin{array}{l}\text { Escudo } \\
\text { Nordeste }\end{array}$} & \multirow[t]{2}{*}{7} & $\begin{array}{l}\text { Gnaisses e Granitos - Tipo } 1 \text { - } \\
\text { Média } 5 \text { valores (Pernambuco) }\end{array}$ & 25,2 & 4,96 & 43,86 & 10,38 & 0,76 & 0,70 & 0,91 & 6,61 & & 1,20 & 14,78 & 10,04 \\
\hline & & Desvio Padrão & 0,4 & 0,38 & 10,60 & 2,67 & 0,58 & 0,26 & 0,49 & 3,56 & & 2,17 & 4,03 & 6,05 \\
\hline & 8 & $\begin{array}{l}\text { Migmatitos e rochas básicas } \\
\text { Tipo } 2 \text { - Guaramiranga CE }\end{array}$ & 24,1 & 7,30 & 177,55 & 40,62 & 4,40 & 21,10 & 2,05 & 152,12 & & 3,73 & 17,50 & 12,13 \\
\hline \multirow{12}{*}{$\begin{array}{l}\text { Escudo } \\
\text { Sudeste }\end{array}$} & \multirow[t]{2}{*}{9} & $\begin{array}{l}\text { Granitos - } \\
\text { média } 13 \text { valores }\end{array}$ & 24,4 & 6,67 & 94,41 & 8,82 & 2,88 & 10,61 & 2,77 & 64,71 & & 2,11 & 3,08 & 22,81 \\
\hline & & Desvio padrão & 6,8 & 0,53 & 43,18 & 4,47 & 1,57 & 7,12 & 1,68 & 30,26 & & 2,69 & 2,29 & 17,32 \\
\hline & 10 & $\begin{array}{l}\text { Rochas Alcalinas - } \\
\text { Araxá MG }\end{array}$ & 23,0 & 7,10 & 56,70 & 0,20 & 1,20 & 11,35 & 3,50 & 55,08 & & 0 & 0 & 11,50 \\
\hline & 11 & $\begin{array}{l}\text { Rochas Alcalinas - } \\
\text { Águas da Prata SP }\end{array}$ & 22,0 & 7,30 & 633,0 & 198,5 & 4,80 & 27,15 & 11,65 & 579,2 & & 59,99 & 10,25 & 33,58 \\
\hline & \multirow{2}{*}{12} & $\begin{array}{l}\text { Gnaisses Tipo } 1 \text { - } \\
\text { média } 33 \text { amostras }\end{array}$ & 20,9 & 5,66 & 43,84 & 4,37 & 2,18 & 2,64 & 1,21 & 21,05 & & 1,27 & 2,02 & 14,30 \\
\hline & & Desvio padrão & 2,1 & 0,23 & 18,12 & 2,68 & 1,42 & 1,66 & 1,23 & 10,34 & & 1,43 & 2,30 & 6,67 \\
\hline & \multirow[t]{2}{*}{13} & $\begin{array}{l}\text { Gnaisses Tipo } 2 \text { - } \\
\text { média } 42 \text { amostras }\end{array}$ & 21,9 & 6,78 & 103,5 & 9,71 & 2,59 & 13,64 & 4,11 & 81,14 & & 2,97 & 2,85 & 20,03 \\
\hline & & Desvio padrão & 1,9 & 0,54 & 48,0 & 8,28 & 1,74 & 8,97 & 2,86 & 42,13 & & 3,98 & 5,58 & 9,07 \\
\hline & 14 & $\begin{array}{l}\text { Metassedimentos - Tipo } 1 \text { - } \\
\text { Itabirito MG }\end{array}$ & 28,0 & 7,80 & 252,48 & 0,70 & 1,50 & 60,12 & 12,75 & 98,44 & & 120,14 & 0 & 17,40 \\
\hline & 15 & $\begin{array}{l}\text { Metassedimentos - Tipo } 2 \text { - } \\
\text { Campo Largo PR }\end{array}$ & 21,0 & 7,80 & 133,41 & 1,20 & 0,40 & 32,06 & 12,41 & 161,22 & & 0 & 0,31 & 10,82 \\
\hline & 16 & $\begin{array}{l}\text { Bcs Cenozóicas - } \\
\text { Caxambu MG }\end{array}$ & 24,8 & 5,05 & 96,61 & 6,79 & 10,88 & 15,78 & 2,49 & 94,05 & & 0,42 & 0 & 17,00 \\
\hline & 17 & $\begin{array}{l}\text { Bcs Cenozóicas - } \\
\text { Mogi das Cruzes SP }\end{array}$ & 22,8 & 7,35 & 130,67 & 34,60 & 2,02 & 3,52 & 1,12 & 122,13 & & 1,97 & 0,87 & 38,90 \\
\hline \multirow{10}{*}{$\begin{array}{l}\text { Bacia } \\
\text { Paraná }\end{array}$} & 18 & $\begin{array}{l}\text { Grupo Tubarão - } \\
\text { Americana SP }\end{array}$ & 23,3 & 8,14 & 109,35 & 30,83 & 0,60 & 5,77 & 0,29 & 92,51 & 3,24 & 2,15 & 0,05 & 22,45 \\
\hline & 19 & $\begin{array}{l}\text { Formação Corumbataí - } \\
\text { Corumbataí SP }\end{array}$ & 22,1 & 7,31 & 229,81 & 10,95 & 3,19 & 46,11 & 13,12 & 236,22 & & 1,10 & 1,04 & 36,64 \\
\hline & \multirow[t]{2}{*}{20} & $\begin{array}{l}\text { Aqüífero Guarani - } \\
\text { média } 9 \text { valores }\end{array}$ & 23,5 & 6,51 & 83,27 & 6,17 & 1,95 & 8,61 & 2,69 & 54,21 & & 1,14 & 1,26 & 15,60 \\
\hline & & Desvio padrão & 2,50 & 0,71 & 36,27 & 7,16 & 0,93 & 4,65 & 2,01 & 23,85 & & 1,74 & 2,24 & 4,08 \\
\hline & \multirow[t]{2}{*}{21} & $\begin{array}{l}\text { Formação Serra Geral - } \\
\text { Tipo } 1 \text { - média } 9 \text { valores }\end{array}$ & 21,0 & 6,93 & 100,12 & 9,67 & 1,40 & 14,14 & 4,56 & 83,84 & & 1,11 & 2,61 & 18,54 \\
\hline & & Desvio padrão & 1,7 & 0,66 & 57,20 & 6,59 & 1,25 & 11,42 & 3,65 & 58,33 & & 1,08 & 4,97 & 11,07 \\
\hline & 22 & $\begin{array}{l}\text { Formação Serra Geral - Tipo } \\
2 \text { - Ibirá SP }\end{array}$ & 24,0 & 10,00 & 288,0 & 97,43 & 0,97 & 0,82 & 0,01 & 30,65 & 81,35 & 47,61 & 2,47 & 36 \\
\hline & \multirow[t]{2}{*}{23} & $\begin{array}{l}\text { Grupo Bauru - Tipo } 1 \text { - } \\
\text { média } 4 \text { valores }\end{array}$ & 25,6 & 6,34 & 84,22 & 5,12 & 3,63 & 12,37 & 2,93 & 61,96 & & 0,07 & 3,48 & 23,18 \\
\hline & & Desvio padrão & 0,9 & 0,65 & 28,86 & 3,08 & 1,87 & 5,00 & 1,29 & 14,39 & & 0,13 & 3,28 & 15,57 \\
\hline & 24 & $\begin{array}{l}\text { Grupo Bauru -Tipo } 2 \text { - } \\
\text { Potirendaba SP }\end{array}$ & 25,2 & 8,84 & 117,70 & 27,51 & 0,84 & 7,85 & 0,64 & 71,14 & 8,80 & 7,50 & 1,31 & 12,77 \\
\hline
\end{tabular}

$\mathrm{N}^{\circ}=$ principais grupos de águas minerais identificados 

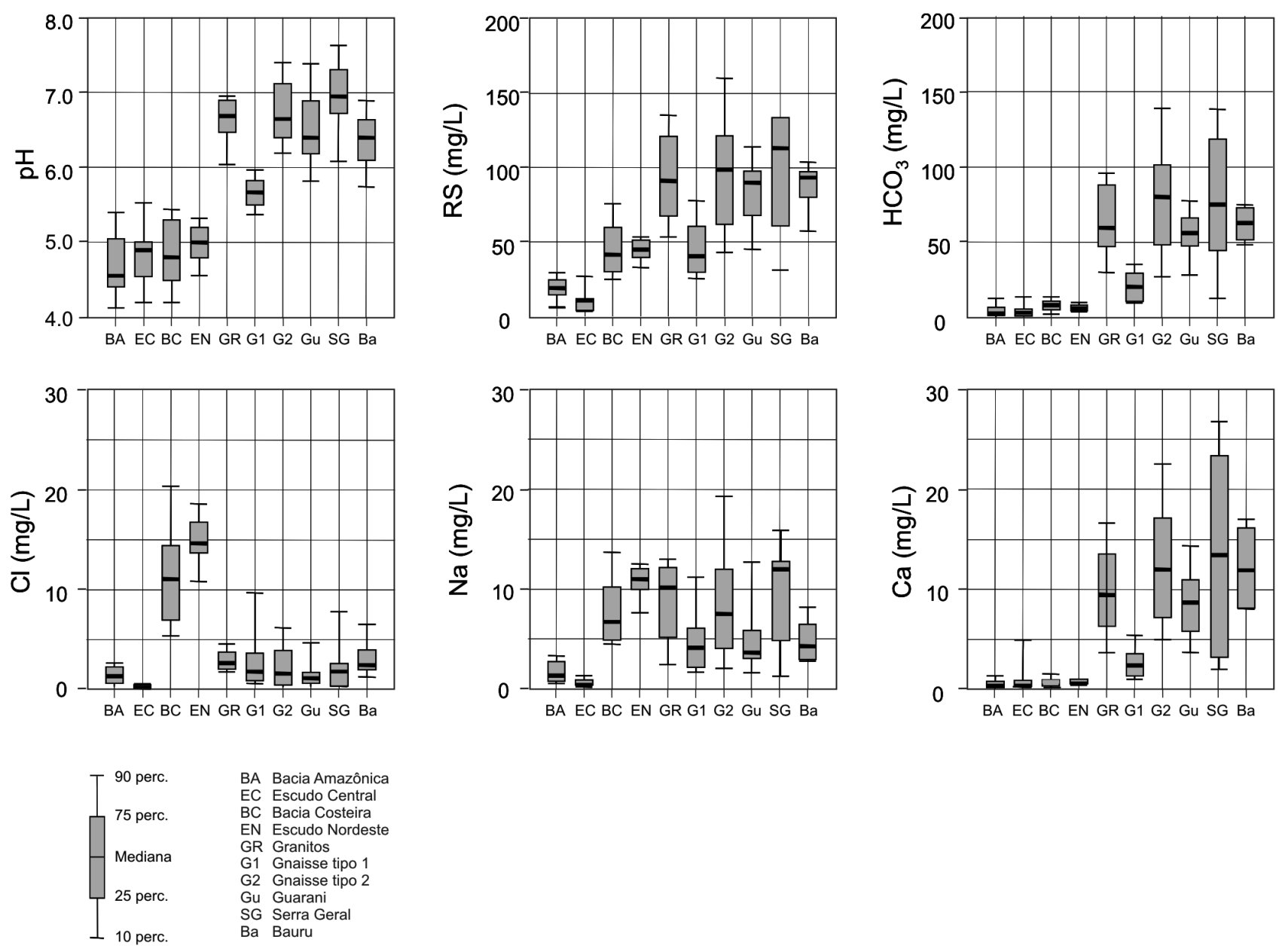

Figura 4 - Faixas de variação de concentrações de algumas espécies químicas em função do contexto hidrogeológico.

dos nos aqüíferos e identifica e sintetiza os processos geoquímicos atuantes que justificam a composição química destas águas.

Rochas pouco reativas ou fortemente intemperizadas As regiões de climas quentes e úmidos exibem mantos de alteração espessos, decorrentes de processos intempéricos intensos, com minerais pouco reativos e altamente lixiviados, resultantes da hidrólise parcial a total dos aluminossilicatos (eliminação da sílica e formação de oxi-hidróxidos de ferro e alumínio). As águas nestes contextos apresentam baixos $\mathrm{pH}(<5,0 \mathrm{em}$ geral) e RS ( $<50 \mathrm{mg} / \mathrm{L})$ (Fig. 4), índices de saturação fortemente negativos para os minerais mais reativos, elevadas concentrações de gás carbônico e de carbono inorgânico total dissolvidos e elevada relação $\left[\mathrm{SiO}_{2} /\right.$ metais alcalinos], indicando dissolução inexpressiva de aluminossilicatos e fonte de sílica relacionada com a dissolução de quartzo/sílica amorfa (Tab. 3). Estas características são notáveis nas águas da Bacia Amazônica (Grupo 1), do Escudo Central (Grupo 2) e do Escudo Nordeste (Grupo 7).

Águas exibindo estas mesmas características são aquelas que percolam rochas com minerais pouco reativos, como os arenitos quartzosos das Bacias Cos- teiras (Grupo 4). Estas águas, juntamente com as do Escudo Nordeste, também exibem forte influência marítima devido às mais elevadas concentrações de cloreto, sendo classificadas como cloretadas sódicas (Figs. 4 e $5 \mathrm{~A})$.

Os diagramas de estabilidade de aluminossilicatos (Fig. 6) apontam a localização das águas de rochas pouco reativas ou fortemente intemperizadas na porção inferior dos gráficos, indicando que as águas apresentam excesso de acidez (reagente) e poucos cátions de base (produtos) dissolvidos. Essas características são típicas de aqüíferos rasos.

Rochas graníticas e gnáissicas No Escudo Sudeste (Grupos 9, 12 e 13 - Tab. 2), o intemperismo de minerais aluminossilicáticos de granitos, xistos e gnaisses é o fator controlador da composição das águas, que geralmente apresentam $\mathrm{pH}$ levemente ácido, variando entre 5,5 e 7,0, e baixa mineralização, com RS variando entre 50 e 100 mg/L (Fig. 4). São águas bicarbonatadas cálcicas a sódicas, virtualmente sem cloreto e sulfato (Figs. 5B a 5D).

As águas provenientes de aqüíferos gnáissicos foram divididas em dois subgrupos em função do $\mathrm{pH}$ e RS (Grupos 12 e 13 - Tabs. 2 e 3), pois as variações 


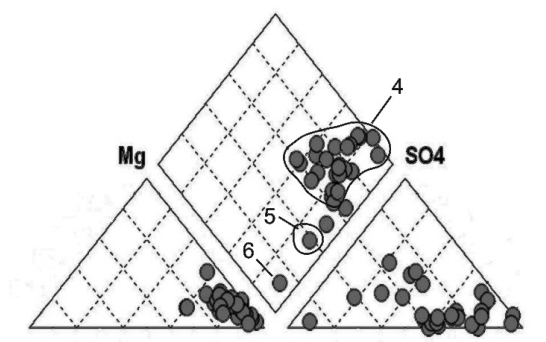

$\mathrm{Ca}$

$\mathrm{Na}+\mathrm{K} \quad \mathrm{HCO} 3$

A-Bacias Costeiras (4 e 5) e Bacia do Parnaíba (6)


$\mathrm{Ca}$

$\mathrm{Na}+\mathrm{K} \mathrm{HCO} 3$

\section{E-Bacias Cenozóicas} do Escudo Sudeste

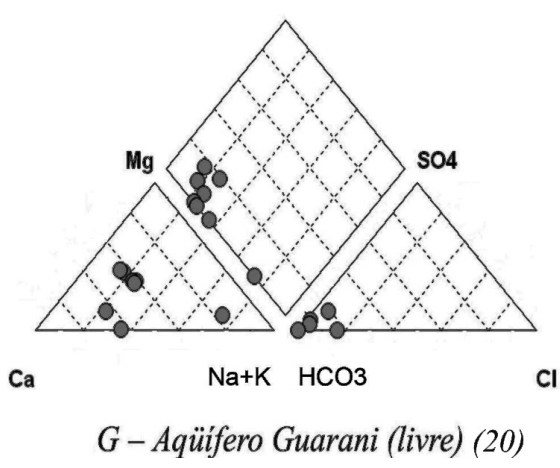

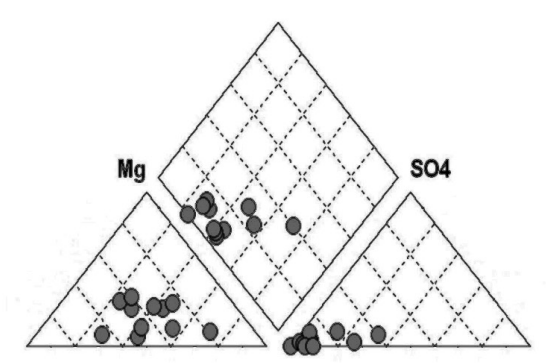

$\mathrm{Ca}$

$\mathrm{Na}+\mathrm{K} \mathrm{HCO} 3$

Cl

$B$ - Granitos do Escudo Sudeste (9)

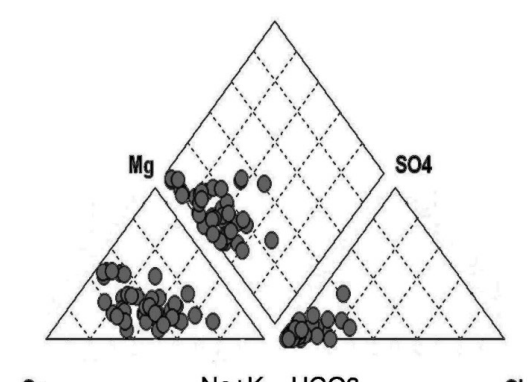

$\mathrm{Ca}$

$\mathrm{Na}+\mathrm{K} \quad \mathrm{HCO} 3$

D - Gnaisses do Escudo Sudeste - Tipo 2 (13)

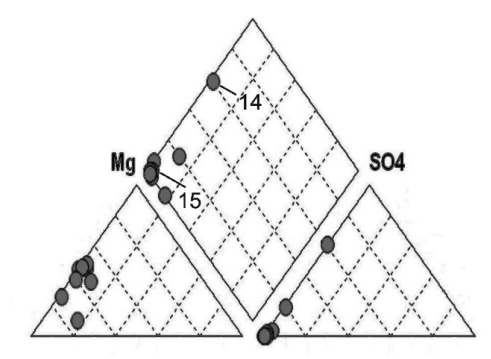

$\mathrm{Ca}$

$\mathrm{Na}+\mathrm{K} \mathrm{HCO} 3$

Cl

F-Metassedimentos do Escudo Sudeste

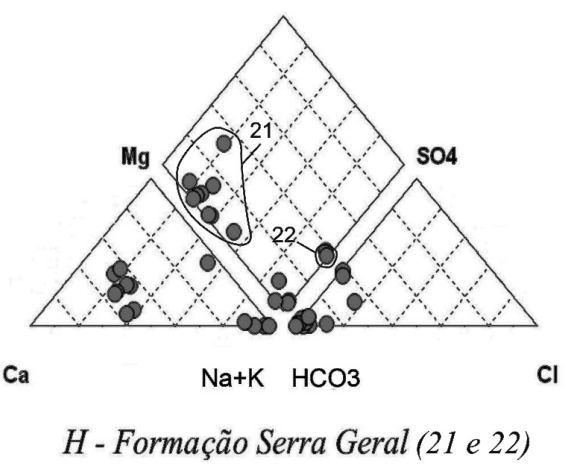

Figura 5 - Classificação hidroquímica das águas minerais (números indicados referem-se aos grupos de águas minerais identificados na tabela 2).

destes parâmetros relacionam-se com a profundidade de circulação da água subterrânea (vide item 4). Notase haver variações na composição dos cátions em cada subgrupo (Figs. 5C e 5D), que se explicam principal- mente devido às características locais da geologia da área de captação. A composição química média apresentada na tabela 2 é, portanto, genérica, prestando-se a demonstrar os fenômenos geoquímicos predominantes 

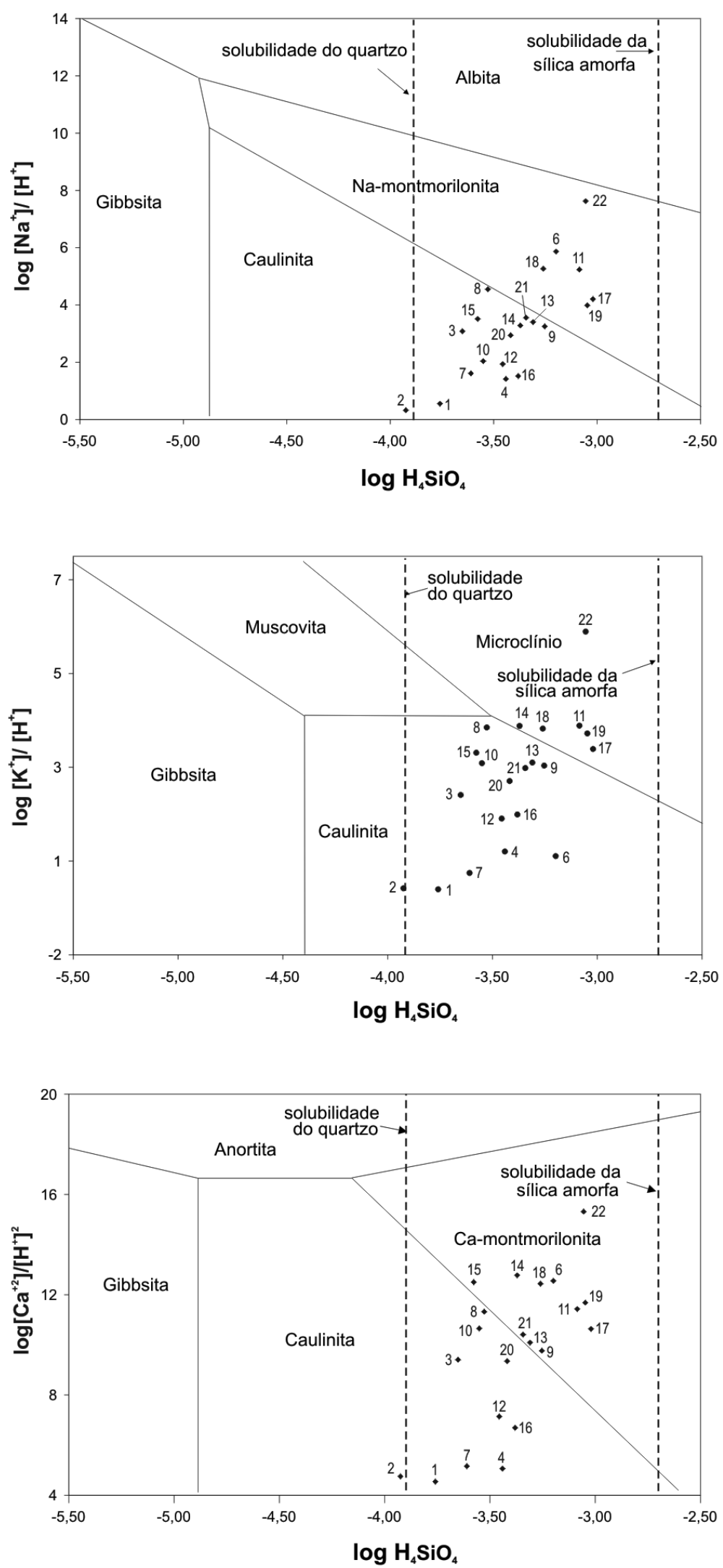

Figura 6 - Diagramas de estabilidade de aluminossilicatos $\left(a 25^{\circ} \mathrm{Ce}\right.$ $1 \mathrm{~atm})$.

neste contexto macro-hidrogeológico.

Apesar das variações observadas, nota-se que as águas de menor mineralização (Tipo 1) são mais ácidas e sódicas que as águas de maior mineralização (Tipo 2), que apresentam pH mais elevado, maior variação nas concentrações dos íons maiores e maior quantidade 
Tabela 3 - Relações iônicas e indices de saturação de alguns minerais reativos

\begin{tabular}{|c|c|c|c|c|c|c|c|c|}
\hline & $\mathrm{N}^{\circ}$ & & $\mathrm{SI}_{\text {calcita }}$ & $\mathrm{SI}_{\text {dolomita }}$ & $\mathrm{SI}_{\text {gipso }}$ & $\mathrm{Pco}_{2}$ (bar) & TIC (mmol) & $\mathrm{HCO}_{3} / \mathrm{SiO}_{2}$ \\
\hline Bacia Amazônica & 1 & Sedimentos Cenozóicos - Média 11 valores & $-6,12$ & $-12,08$ & $-5,33$ & 0,1 & 10,8 & 0,65 \\
\hline Escudo Central & 2 & R. ígneas/metam. intemp. - Média 11 valores & $-6,29$ & $-12,63$ & $-7,01$ & 0,043 & 11,2 & 0,70 \\
\hline São Francisco & 3 & Grupo Bambuí - Brasília DF & $-2,21$ & $-4,55$ & $-3,74$ & 0,012 & 8,84 & 5,40 \\
\hline \multirow{2}{*}{ Bacias Costeiras } & 4 & Sedimentos - Tipo 1 - média 25 valores & $-5,56$ & $-10,75$ & $-4,70$ & 0,113 & 10,4 & 0,56 \\
\hline & 5 & Sedimentos - Tipo 2 - Mun. Aquiraz CE & $-0,33$ & $-0,49$ & $-3,13$ & 0,0009 & 8,61 & 5,83 \\
\hline Bacia Parnaíba & 6 & Fm. Pedra de Fogo - Teresina - PI & 0,12 & $-0,13$ & $-3,53$ & 0,0018 & 8,12 & 11,35 \\
\hline \multirow{2}{*}{ Escudo Nordeste } & 7 & Tipo 1 - Média 5 valores (PE) & $-5,66$ & $-10,86$ & $-5,18$ & 0,074 & 10,6 & 0,71 \\
\hline & 8 & Tipo 2 - Guaramiranga CE & $-0,56$ & $-1,79$ & $-3,35$ & 0,007 & 7,89 & 13,44 \\
\hline \multirow{9}{*}{ Escudo Sudeste } & 9 & Granitos - média 13 valores & $-1,81$ & $-3,85$ & $-3,82$ & 0,013 & 8,51 & 3,04 \\
\hline & 10 & Alcalinas - Araxá - MG & $-1,44$ & $-3,01$ & & 0,004 & 8,56 & 5,13 \\
\hline & 11 & Alcalinas - Águas da Prata - SP & 0,01 & 0,04 & $-2,22$ & 0,024 & 7,35 & 18,48 \\
\hline & 12 & Gnaisses Tipo 1 - média 33 amostras & $-3,94$ & $-7,81$ & $-4,58$ & 0,045 & 9,61 & 1,58 \\
\hline & 13 & Gnaisses Tipo 2 - média 42 amostras & $-1,55$ & $-3,22$ & $-3,58$ & 0,013 & 8,35 & 4,34 \\
\hline & 14 & Metassedimentos - Itabirito - MG & 0,19 & 0,01 & $-1,53$ & 0,001 & 7,65 & 6,06 \\
\hline & 15 & Metassedimentos - Campo Largo - PR & 0,10 & 0,19 & $-6,77$ & 0,002 & 7,73 & 15,96 \\
\hline & 16 & Bcs Cenozóicas - Caxambu-MG & $-3,11$ & $-6,66$ & $-4,37$ & 0,817 & 8,18 & 5,93 \\
\hline & 17 & Bcs Cenozóicas - Mogi das Cruzes - SP & $-1,37$ & $-2,86$ & $-4,34$ & 0,005 & 8,75 & 3,36 \\
\hline \multirow{7}{*}{ Bacia Paraná } & 18 & Grupo Tubarão - Americana - SP & $-0,46$ & $-1,84$ & $-4,08$ & 0,001 & 8,62 & 4,73 \\
\hline & 19 & Formação Corumbataí - Corumbataí - SP & $-0,07$ & $-0,29$ & $-3,62$ & 0,010 & 7,42 & 6,91 \\
\hline & 20 & Aqüífero Guarani - média 9 valores & $-2,15$ & $-4,43$ & $-4,16$ & 0,020 & 8,68 & 3,72 \\
\hline & 21 & Formação Serra Geral - média 9 valores & $-1,38$ & $-2,84$ & $-4,00$ & 0,009 & 8,33 & 4,84 \\
\hline & 22 & Formação Serra Geral -Ibirá - SP & 0,58 & $-0,39$ & $-3,67$ & 0,00001 & 9,45 & 5,84 \\
\hline & 23 & Grupo Bauru - Tipo 1 - média 4 valores & $-2,08$ & $-4,44$ & $-5,26$ & 0,028 & 8,44 & 2,86 \\
\hline & 24 & Grupo Bauru - Tipo 2 - Potirendaba - SP & 0,32 & $-0,11$ & $-3,41$ & 0,0001 & 8,55 & 7,47 \\
\hline
\end{tabular}

\begin{tabular}{|c|c|c|c|c|c|c|c|}
\hline & $\mathrm{N}^{\mathrm{o}}$ & & $\begin{array}{c}\mathrm{Na} / \\
(\mathrm{Na}+\mathrm{Cl})\end{array}$ & $\begin{array}{c}\mathrm{Ca} / \\
\left(\mathrm{Ca}+\mathrm{SO}_{4}\right)\end{array}$ & $\begin{array}{c}\mathrm{SiO}_{2} / \\
(\mathrm{Na}+\mathrm{K}-\mathrm{Cl})\end{array}$ & $\begin{array}{c}(\mathrm{Na}+\mathrm{K}-\mathrm{Cl}) / \\
(\mathrm{Na}+\mathrm{K}-\mathrm{Cl}+\mathrm{Ca})\end{array}$ & $\begin{array}{c}\mathrm{Mg} / \\
(\mathrm{Mg}+\mathrm{Ca})\end{array}$ \\
\hline Bacia Amazônica & 1 & Sedimentos Cenozóicos - Média 11 valores & 0,66 & 0,67 & 1,93 & 0,63 & 0,53 \\
\hline Escudo Central & 2 & R. ígneas/metam. intemp. - Média 11 valores & 0,82 & 0,97 & 2,39 & 0,63 & 0,41 \\
\hline São Francisco & 3 & Grupo Bambuí - Brasília DF & 1,00 & 0,80 & 0,43 & 0,50 & 0,37 \\
\hline \multirow{2}{*}{ Bacias Costeiras } & 4 & Sedimentos - Tipo 1 - média 25 valores & 0,51 & 0,42 & 2,49 & 0,67 & 0,65 \\
\hline & 5 & Sedimentos - Tipo 2 - Mun. Aquiraz CE & 0,83 & 0,18 & 0,15 & 0,95 & 0,58 \\
\hline Bacia Parnaíba & 6 & Fm. Pedra de Fogo - Teresina - PI & 0,93 & 0,58 & 0,09 & 0,94 & 0,30 \\
\hline \multirow{2}{*}{ Escudo Nordeste } & 7 & Tipo 1 - Média 5 valores (PE) & 0,52 & 0,58 & 2,84 & 0,61 & 0,68 \\
\hline & 8 & Tipo 2 - Guaramiranga CE & 0,78 & 0,93 & 0,13 & 0,57 & 0,14 \\
\hline \multirow{9}{*}{ Escudo Sudeste } & 9 & Granitos - média 13 valores & 0,82 & 0,92 & 0,94 & 0,41 & 0,30 \\
\hline & 10 & Alcalinas - Araxá - MG & 1,00 & 1,00 & 4,47 & 0,07 & 0,34 \\
\hline & 11 & Alcalinas - Águas da Prata - SP & 0,97 & 0,52 & 0,06 & 0,86 & 0,41 \\
\hline & 12 & Gnaisses Tipo 1 - média 33 amostras & 0,77 & 0,83 & 1,16 & 0,59 & 0,43 \\
\hline & 13 & Gnaisses Tipo 2 - média 42 amostras & 0,84 & 0,92 & 0,75 & 0,37 & 0,33 \\
\hline & 14 & Metassedimentos - Itabirito - MG & 1,00 & 0,55 & 3,87 & 0,02 & 0,26 \\
\hline & 15 & Metassedimentos - Campo Largo - PR & 0,86 & 1,00 & 3,08 & 0,03 & 0,39 \\
\hline & 16 & Bcs Cenozóicas - Caxambu - MG & 1,00 & 0,99 & 0,45 & 0,42 & 0,21 \\
\hline & 17 & Bcs Cenozóicas - Mogi das Cruzes - SP & 0,98 & 0,81 & 0,39 & 0,90 & 0,34 \\
\hline \multirow{7}{*}{ Bacia Paraná } & 18 & Grupo Tubarão - Americana - SP & 1,00 & 0,87 & 0,25 & 0,82 & 0,08 \\
\hline & 19 & Formação Corumbataí - Corumbataí - SP & 0,94 & 0,99 & 1,06 & 0,19 & 0,32 \\
\hline & 20 & Aqüífero Guarani - média 9 valores & 0,88 & 0,95 & 0,84 & 0,40 & 0,34 \\
\hline & 21 & Formação Serra Geral - média 9 valores & 0,85 & 0,97 & 0,74 & 0,35 & 0,35 \\
\hline & 22 & Formação Serra Geral -Ibirá - SP & 0,98 & 0,04 & 0,13 & 0,99 & 0,04 \\
\hline & 23 & Grupo Bauru - Tipo 1 - média 4 valores & 0,69 & 1,00 & 1,63 & 0,26 & 0,28 \\
\hline & 24 & Grupo Bauru - Tipo 2 - Potirendaba - SP & 0,97 & 0,71 & 0,17 & 0,75 & 0,12 \\
\hline
\end{tabular}

$\mathrm{N}^{o}=$ principais grupos de águas minerais identificados (ver Tab. 2). 
Tabela 4 - Processos geoquímicos atuantes nas águas minerais.

\begin{tabular}{|c|c|c|c|}
\hline & $\mathrm{N}^{\circ}$ & Rochas/ Mineralogia & Processos Hidrogeoquímicos \\
\hline $\begin{array}{c}\text { Bacia } \\
\text { Amazônica }\end{array}$ & 1 & $\begin{array}{l}\text { Sedimentos cenozóicos compostos por } \\
\text { areias quartzosas e argilominerais }\end{array}$ & $\begin{array}{l}\text { Água subterrânea de baixa mineralização e ácida (excesso de reagentes), percolando } \\
\text { minerais de rochas/sedimentos pouco reativos. Ocorrência de hidrólise parcial a } \\
\text { total de aluminossilicatos, gerando caulinita e (possivelmente) gibsita. }\end{array}$ \\
\hline $\begin{array}{l}\text { Escudo } \\
\text { Central }\end{array}$ & 2 & $\begin{array}{l}\text { Rochas ígneas e metamórficas, } \\
\text { fortemente lixiviadas e intemperizadas } \\
\text { (lateritas). }\end{array}$ & $\begin{array}{l}\text { Mesmos processos do contexto da Bacia Amazônica. Águas ácidas e de baixa } \\
\text { mineralização de aqǘf́feros rasos e de rápido tempo de trânsito. }\end{array}$ \\
\hline $\begin{array}{l}\text { São } \\
\text { Francisco }\end{array}$ & 3 & $\begin{array}{l}\text { Metassedimentos (metassiltitos) do } \\
\text { Grupo Bambuí }\end{array}$ & $\begin{array}{l}\text { Intemperismo de minerais aluminossilicáticos, produzindo argilominerais tipo } \\
\text { caulinita, associado a águas bicarbonatadas cálcicas e cálcico-sódicas. Possível } \\
\text { influência da geoquímica de carbonatos. }\end{array}$ \\
\hline Bacias & 4 & $\begin{array}{l}\text { Tipo } 1 \text { - areias, siltes, argilas e } \\
\text { cascalhos, com mineralogia pouco } \\
\text { reativa aos processos de intemperismo }\end{array}$ & $\begin{array}{l}\text { Águas de circulação rasa, baixo } \mathrm{pH} \text {, cloretadas sódicas, com forte influência } \\
\text { marinha. }\end{array}$ \\
\hline & 5 & $\begin{array}{l}\text { Tipo } 2 \text { - sedimentos das águas Tipo } \\
1 \text {, mais provável influência de rochas } \\
\text { gnáissicas do embasamento cristalino }\end{array}$ & $\begin{array}{l}\text { Contribuição marinha e troca catiônica do sódio pelo cálcio na matriz do aqüífero. } \\
\text { Águas bicarbonatadas-cloretadas sódicas de circulação profunda. }\end{array}$ \\
\hline $\begin{array}{c}\text { Bacia } \\
\text { Parnaíba }\end{array}$ & 6 & $\begin{array}{l}\text { Arenitos, siltitos e folhelhos da Fm. } \\
\text { Pedra de Fogo, com minerais acessórios } \\
\text { reativos (sílex, calcários e gipsita) }\end{array}$ & $\begin{array}{l}\text { Influência da geoquímica dos carbonatos (calcita supersaturada). Águas } \\
\text { bicarbonatadas sódicas de fluxos regionais e profundos. Fonte de sódio por } \\
\text { contribuição marinha e por troca catiônica. }\end{array}$ \\
\hline & 7 & $\begin{array}{l}\text { Tipo } 1-\text { Gnaisses } \quad \text { e } \text { granitos } \\
\text { (Pernambuco) }\end{array}$ & $\begin{array}{l}\text { Influência marinha mais intensa que o intemperismo de aluminossilicatos. Águas de } \\
\text { circulação rasa, semelhantes às águas tipo } 1 \text { das Bacias Costeiras. }\end{array}$ \\
\hline & 8 & $\begin{array}{l}\text { Tipo } 2 \text { - migmatitos e gnaisses, com } \\
\text { corpos de metacalcários, anfibolitos e } \\
\text { metabasitos }\end{array}$ & $\begin{array}{l}\text { Dissolução de carbonatos, associado com troca catiônica do sódio pelo cálcio na } \\
\text { matriz do aqüífero. Contribuição iônica por evaporação. Montmorilonitas estáveis. } \\
\text { Águas de circulação profunda. }\end{array}$ \\
\hline \multirow{4}{*}{$\begin{array}{l}\text { Escudo } \\
\text { Sudeste }\end{array}$} & $\begin{array}{c}9,12 \mathrm{e} \\
13\end{array}$ & $\begin{array}{l}\text { Xistos, gnaisses, migmatitos e granitos } \\
\text { do embasamento cristalino, contendo } \\
\text { K-feldspato, albita, anortita, micas, } \\
\text { piroxênios e anfibólios }\end{array}$ & $\begin{array}{l}\text { Dissolução de aluminossilicatos. Águas de circulação rasa são mais sódicas (albitas), } \\
\text { de pH ácido; caulinita é o mineral estável. Águas profundas são mais cálcicas } \\
\text { (anortita, piroxênios e anfibólios) e de pH neutro. }\end{array}$ \\
\hline & 10 e 11 & $\begin{array}{l}\text { Rochas alcalinas (flogopititos/ } \\
\text { carbonatitos }-10 ; \quad \text { foiaítos/ } \\
\text { fonólitos - 11), com minerais acessórios } \\
\text { importantes (barita, pirita, fluorita }\end{array}$ & $\begin{array}{l}\text { Intemperismo de minerais de rochas alcalinas. Bicarbonatadas sódicas (feldspatóides, } \\
\text { feldspatos e piroxênios) ou cálcicas (carbonatitos). Sulfato originado por oxidação } \\
\text { de pirita. Fluoreto e bário respectivamente por dissolução de fluorita e barita. Águas } \\
\text { de elevada radioatividade temporária e de circulação rasa (10) ou profunda (11). }\end{array}$ \\
\hline & 14 e 15 & $\begin{array}{l}\text { Rochas metamórficas de baixo grau. } \\
\text { Dolomitos (14/15), filitos dolomíticos, } \\
\text { calcários, ś́lica e pirita (14) }\end{array}$ & $\begin{array}{l}\text { Águas bicarbonatadas cálcicas a cálcicas-magnesianas originadas com a dissolução } \\
\text { de carbonatos. Oxidação de pirita gera sulfato e acidez, que é neutralizada na } \\
\text { dissolução de carbonatos (14). Soluções saturadas em calcita e dolomita. }\end{array}$ \\
\hline & 16 e 17 & $\begin{array}{l}\text { Depósitos fluviais cenozóicos: areias, } \\
\text { siltes e argilas }(16 / 17) \text {. Níveis de } \\
\text { matéria orgânica associados com } \\
\text { depósitos argilosos (16). }\end{array}$ & $\begin{array}{l}\text { Dissolução de aluminossilicatos. Águas de circulação rasa são carbogasosas naturais } \\
\text { (16), devido a degradação de matéria orgânica em níveis argilosos orgânicos; } \\
\text { potássio elevado devido a possível dissolução de ilita. Caulinita estável. As águas } \\
\text { de circulação profunda (17) possuem provável aporte de sódio por troca iônica e } \\
\text { montmorilonitas estáveis. }\end{array}$ \\
\hline \multirow{4}{*}{$\begin{array}{l}\text { Bacia do } \\
\text { Paraná }\end{array}$} & 18 e 19 & $\begin{array}{l}\text { Tilitos, diamictitos, arenitos }(18) \text {; } \\
\text { e folhelhos e siltitos com bancos } \\
\text { carbonáticos, silexíticos e de arenitos } \\
\text { finos (19) }\end{array}$ & $\begin{array}{l}\text { Dissolução de aluminossilicatos (18), formando águas bicarbonatadas sódicas. } \\
\text { Dissolução de carbonatos e de sílica, formando águas bicarbonatadas cálcicas com } \\
\text { calcita saturada e com sílica elevada (19). Águas de circulação profunda, com } \\
\text { montmorilonitas estáveis. }\end{array}$ \\
\hline & 20 & Areias quartzosas fluviais e eólicas & $\begin{array}{l}\text { Águas de circulação rasa na área de recarga são bicarbonatadas cálcicas, com baixo } \\
\text { pH e sólidos dissolvidos. Influência da geoquímica de silicatos, sem contribuição } \\
\text { de carbonatos, sulfatos e cloretos. Águas de circulação superprofunda }(\sim 1000 \mathrm{~m}) \\
\text { possuem geoquímica mais complexa: carbonatos saturados e troca iônica do sódio } \\
\text { pelo cálcio; elevados pH e sólidos dissolvidos. }\end{array}$ \\
\hline & 21 e 22 & $\begin{array}{l}\text { Basaltos toleíticos: plagioclásio cálcico } \\
\text { e piroxênio (augita) }\end{array}$ & $\begin{array}{l}\text { Águas de fluxos raso e profundo }(<150 \mathrm{~m}) \text { são bicarbonatadas cálcicas, originadas } \\
\text { pelo intemperismo de plagioclásio cálcico. Caulinitas estáveis. Águas de fluxos } \\
\text { superprofundos }(>1000 \mathrm{~m}) \text { são bicarbonatadas sódicas, semelhantes às águas do } \\
\text { Aqüífero Guarani confinado - provável fluxo ascendente através de fraturas. }\end{array}$ \\
\hline & 23 e 24 & $\begin{array}{l}\text { Arenitos fluviais com lentes de siltitos } \\
\text { e argilitos e cimentação carbonática }\end{array}$ & $\begin{array}{l}\text { Águas de fluxo raso são bicarbonatadas cálcicas a cálcicas-sódicas. Águas de } \\
\text { fluxo profundo }(>100 \mathrm{~m}) \text { são bicarbonatadas sódicas. Carbonatos saturados em } \\
\text { profundidade; enriquecimento de sódio em profundidade devido à troca iônica do } \\
\text { sódio pelo cálcio }\end{array}$ \\
\hline
\end{tabular}

$\mathrm{N}^{\mathrm{o}}=$ principais grupos de águas minerais identificados (ver Tab. 2). 
de cálcio (Fig. 4). Os núcleos das nuvens de pontos dos diagramas de Piper (Figs. 5C e 5D) indicam estas características. As águas mais profundas (em geral, maiores que $70 \mathrm{~m}$ ) tendem a ser mais cálcicas pois os minerais ricos em cálcio e magnésio (anortita, piroxênios e anfibólios) são intemperizados mais rapidamente que os minerais sódicos e potássicos (albita e K-feldspato), de acordo com a série de Goldich. As águas de granitos (Grupo 9) apresentam maior dispersão de dados (Figs. 4 e 5B), mas suas características gerais são semelhantes à população conjunta das águas dos gnaisses rasos e profundos.

As relações iônicas (Tab. 3) indicam que o sódio é proveniente da dissolução da albita $([\mathrm{Na} / \mathrm{Cl}]>50 \%)$, o cálcio da dissolução de anortita $\left(\left[\mathrm{Ca} / \mathrm{SO}_{4}\right]>50 \%\right.$ e $[\mathrm{Na} /$ Ca] entre 0,2 e 0,8 - Hounslow 1995), o magnésio da dissolução de minerais máficos (e que se encontram em pequenas proporções em rochas graníticas, pois a relação $[\mathrm{Mg} / \mathrm{Ca}]<50 \%$ ) e o potássio a partir da dissolução de micas, não havendo sinais de participação de minerais carbonáticos na matriz do aqüífero (índices de saturação negativos para carbonatos). Estas características se repetem na quase totalidade das análises, independente das variações da composição química das amostras.

Os gráficos de estabilidade de aluminossilicatos (Fig. 6) indicam a caulinita como o mineral mais estável para as águas de circulação rasa do Escudo Sudeste (Grupo 12). As águas de circulação mais profunda (Grupo 13) tendem a encontrar-se numa posição mais elevada dos gráficos, mais próximas dos campos de estabilidade das montmorilonitas.

Em regiões litorâneas, as rochas cristalinas podem ser recobertas por sedimentos cenozóicos, e algumas águas de composição química diferenciada podem ser identificadas. Em Aquiraz (CE) (Grupo 5) as águas são de $\mathrm{pH}$ neutro a básico, com RS elevado $(\approx 300$ $\mathrm{mg} / \mathrm{L}$ ), fortemente sódicas, virtualmente sem cálcio e predominantemente bicarbonatadas, apesar de também apresentarem concentrações significativas de sulfato e cloreto, sendo, portanto, diferentes das demais águas das Bacias Costeiras (Fig. 5A). A tabela 3 aponta para um largo predomínio do sódio sobre o cloreto, indicando a existência de outras fontes de sódio além daquela de origem marinha. Como a origem do sulfato está ligada à dissolução de gipso e a relação $\left[\mathrm{Ca} / \mathrm{SO}_{4}\right]$ indica predomínio do sulfato sobre o cálcio, a maior oferta de sódio no aqǘf́rero relaciona-se com o processo de troca iônica do sódio pelo cálcio na matriz do aqǘfero. Provavelmente estas águas são originadas das porções mais profundas do aqüífero cristalino subjacente ao Grupo Barreiras, que, segundo Cavalcante (1998), geralmente possuem elevadas quantidades de sais dissolvidos.

Sedimentos Cenozóicos As águas que percolam depósitos cenozóicos sedimentados sobre rochas cristalinas do Escudo Sudeste apresentam baixa mineralização, são fortemente bicarbonatadas, apresentam variação na composição catiônica (Fig. 5E) e mineralizam-se pelo intemperismo de minerais aluminossilicáticos. Dois exemplos são apresentados na tabela 2 (Grupos 16 e 17).

As águas do Grupo 16, típicas do Circuito das Águas mineiro, apresentam uma componente que lhes denota natureza carbogasosa natural. Atribui-se a origem do gás carbônico à degradação de matéria orgânica contida em camadas argilosas confinantes do aqǘfero sedimentar quaternário de planícies aluviais. As condições redutoras junto com o $\mathrm{pH}$ ácido são também responsáveis pela solubilidade do ferro e manganês nas águas. Uma característica das águas de Caxambu e São Lourenço (MG) refere-se às notáveis concentrações de potássio, cujos valores absolutos são os mais elevados dentre as águas envasadas do Brasil. O processo geoquímico mais plausível para a solubilização do potássio seria a dissolução da ilita, provocada pela acidez mais intensa, que é continuamente gerado pela degradação da matéria orgânica.

Bacias sedimentares cenozóicas mais espessas (>100 m), como a de São Paulo, podem apresentar águas do tipo bicarbonatada sódica e com $\mathrm{pH}$ neutro (Grupo 17), e relações iônicas que indicam que a origem dos íons deve-se à dissolução de minerais silicáticos, com influência marinha desprezível e pouca ou nenhuma contribuição de minerais reativos. Estas águas são típicas de fluxos mais profundos do aqüífero. A relação $\left[\mathrm{SiO}_{2} / \mathrm{Na}\right]<1,0$ (Tab. 3) indica que o sódio originou-se provavelmente por troca iônica com esmectitas, que é o argilomineral mais estável no aqüífero (Fig. 6).

Rochas com minerais carbonáticos As águas dos grupos 6 (Bacia do Parnaíba), 8 (Escudo Nordeste tipo 2), 14 e 15 (metassedimentos do Escudo Sudeste - Fig. 5F), e 19 e 23/24 (Bacia do Paraná), tem suas composições químicas controladas pela dissolução de minerais carbonáticos. Essas águas são bicarbonatadas cálcicas a cálcicas-magnesianas, $\operatorname{com} \mathrm{pH}$ neutro a alcalino e valores de RS superiores à média das águas brasileiras $(100<\mathrm{RS}<250 \mathrm{mg} / \mathrm{L})$. Normalmente apresentamse saturadas ou supersaturadas em calcita e dolomita e exibem elevadas relações $\left[\mathrm{HCO}_{3} / \mathrm{SiO}_{2}\right]$ e $\left[\mathrm{Ca} / \mathrm{SO}_{4}\right]$ (Tab. 3).

A água do Grupo 14 é extraída da região da Sinclinal da Moeda (Itabirito - MG), através de fraturas de filitos dolomíticos da Formação Fecho do Funil. Dada à relativamente elevada temperatura da água e à sua composição bicarbonatada-sulfatada cálcica (Fig. 5F), supõe-se que a sua origem seja de fluxos ascendentes da Formação Gandarela, onde ocorrem dolomitos, filitos dolomíticos e calcários com pirita disseminada como mineral acessório (van Dorr 1969). O modelo hidrogeoquímico corresponde inicialmente à oxidação da pirita, gerando sulfato e acidez para a solução, que é neutralizada no ataque químico aos minerais carbonáticos.

A água do Grupo 15 (Campo Largo - PR) situa-se no contexto de mármores dolomíticos do Grupo Açungui (Mineropar 1986). As relações iônicas da tabela 3 são concordantes com o contexto geológico regional, indicando predomínio da geoquímica de car- 
bonatos, seja pela elevada relação $\left[\mathrm{HCO}_{3} / \mathrm{SiO}_{2}\right]$, como pelas baixas relações $[(\mathrm{Na}+\mathrm{K}) / \mathrm{Ca}]$ e $[\mathrm{Mg} / \mathrm{Ca}]$, esta última sendo proporcional à composição da rocha dolomítica (Tab. 3). Os índices de saturação positivos da calcita e dolomita são indicativos de que estes minerais encontram-se supersaturados no aqüífero. Em Campos do Jordão (SP), ocorrem águas minerais muito semelhantes a esta água do Grupo 15, tendo a mesma origem geoquímica.

No caso particular das águas do Grupo 19 (Formação Corumbataí), além do controle geoquímico por minerais carbonáticos, as concentrações elevadas de sílica são devidas à dissolução dos minerais dos bancos silexíticos existentes (IPT 1981).

Os grupos 23 e 24 são relacionados com o Grupo Bauru, que apresentam formações contendo minerais carbonáticos no cimento das rochas areníticas (IPT 1981). No Grupo 23 predominam águas bicarbonatadas cálcicas a cálcico-sódicas, com pH levemente ácido, $\mathrm{RS} \approx 90 \mathrm{mg} / \mathrm{L}$ e minerais reativos em condições de dissolução (Tab. 3). No Grupo 24 ocorrem águas bicarbonatadas sódicas, com $\mathrm{pH}$ alcalino, $\mathrm{RS}=120 \mathrm{mg} / \mathrm{L}$

Tabela 5 - Águas minerais brasileiras com conteúdo de nitrato maior que $9 \mathrm{mg} / \mathrm{L}$.

\begin{tabular}{|c|c|c|c|c|c|c|}
\hline Localização & UF & $\mathrm{pH}$ & R.S. $(\mathrm{mg} / \mathrm{L})$ & $\mathrm{Cl}^{-}(\mathrm{mg} / \mathrm{L})$ & $\mathrm{NO}_{3}^{-}(\mathrm{mg} / \mathrm{L})$ & Contexto geológico \\
\hline Boituva & SP & 4,31 & 91,11 & 7,78 & 49,34 & Sedimentos Gr. Tubarão - Bc. Paraná \\
\hline Porto Alegre & RS & 5,83 & 152,83 & 21,86 & 48,00 & Granitos - Esc. Meridional \\
\hline Alm. Tamandaré & PR & 6,30 & 263,09 & 17,58 & 39,70 & Metassed. Gr. Açungui - Esc. Sudeste \\
\hline Serra Negra & SP & 6,30 & 144,00 & 3,24 & 38,97 & Gnaisses Cp. Amparo - Esc. Sudeste \\
\hline Cafelândia & SP & 6,20 & 111,00 & 15,53 & 36,00 & Sedimentos Gr. Bauru - Bc. Paraná \\
\hline Piracicaba & SP & 4,00 & 56,76 & 4,71 & 33,46 & Sedimentos Gr. Tubarão - Bc. Paraná \\
\hline Itaquaquecetuba & $\mathrm{SP}$ & 5,20 & 87,77 & 13,73 & 31,19 & Granitóides - Esc. Sudeste \\
\hline São Paulo & SP & 5,05 & 126,10 & 33,40 & 30,30 & Sedimentos Cenozóicos - Bc. São Paulo \\
\hline Itaperuna & $\mathrm{RJ}$ & 5,60 & 230,00 & 9,04 & 25,02 & Sedimentos Cenozóicos \\
\hline São Paulo & SP & 5,02 & 65,00 & 14,34 & 18,40 & Sedimentos Cenozóicos - Bc. São Paulo \\
\hline Armazém & $\mathrm{SC}$ & 6,45 & 72,00 & 5,70 & 14,88 & Granitóides - Esc. Sudeste \\
\hline Mococa & SP & 6,32 & 104,18 & 0,86 & 14,10 & Gnaisses Cp. Varginha - Esc. Sudeste \\
\hline Fortaleza & $\mathrm{CE}$ & 4,96 & 160,2 & 69,43 & 13,38 & Sedimentos Cenozóicos - Fm. Barreiras \\
\hline Parnamirim & $\mathrm{RN}$ & 5,30 & 49,00 & 11,45 & 12,45 & Sedimentos Cenozóicos - Fm. Barreiras \\
\hline Campo Grande & MS & 6,70 & 102,00 & 3,55 & 12,15 & Basaltos Fm S.Geral - Bc. Paraná \\
\hline Águas Lindóia & SP & 5,03 & 97,20 & 4,54 & 12,03 & Gnaisses Cp. Amparo - Esc. Sudeste \\
\hline Serra Negra & SP & 5,50 & 52,00 & 0,58 & 11,81 & Gnaisses Cp. Amparo - Esc. Sudeste \\
\hline Elias Fausto & SP & 5,19 & 39,69 & 2,07 & 10,65 & Sedimentos Gr. Tubarão - Bc. Paraná \\
\hline Lambari & MG & 4,70 & 45,00 & 2,60 & 10,22 & Sedimentos Cenozóicos \\
\hline Itu & SP & 7,25 & 239,38 & 28,19 & 9,64 & Gnaisses Cp. Amparo - Esc. Sudeste \\
\hline Três Lagoas & MS & 5,76 & 48,36 & 3,04 & 9,4 & Sedimentos Gr. Bauru - Bc. Paraná \\
\hline Jaguariúna & SP & 6,02 & 79,95 & 1,02 & 9,40 & Gnaisses Cp. Amparo - Esc. Sudeste \\
\hline Palmares Pta & SP & 5,83 & 53,71 & 0,43 & 9,20 & Sedimentos Gr. Bauru - Bc. Paraná \\
\hline Manaus & $\mathrm{AM}$ & 5,40 & 49,00 & 3,49 & 9,00 & Sedimentos Gr. Barreiras \\
\hline
\end{tabular}

R.S.: Resíduo Seco 
e condições de supersaturação de calcita. As águas do primeiro grupo são típicas de sistemas de fluxos rasos e locais, enquanto que as do segundo tipo são de circulação regional. Os principais fenômenos hidroquímicos que explicam a passagem de águas cálcicas para sódicas, do aqüífero raso para o profundo, seriam uma conjugação de precipitação de calcita juntamente com a troca catiônica do sódio pelo cálcio em profundidade (Campos 1993; Gutierrez \& Hirata 2004).

Rochas alcalinas As rochas alcalinas, devido às associações mineralógicas pouco comuns, geram águas com características particulares. Isso é notável no Complexo Alcalino-Carbonatítico Barreiro (Grupo 10, Araxá - MG), onde fluxos rasos associados ao espesso manto de intemperismo $(120 \mathrm{~m})$ e à presença de minerais como a flogopita, olivina, calcita, apatita, além de veios de barita, de dolomita ferrosa com pirita, e de silexito com monazita (Torres e Gaspar 1995), geram uma água de baixo RS $(56,7 \mathrm{mg} / \mathrm{L})$, $\mathrm{pH}$ neutro e largo predomínio do cálcio (Tab. 2). A relação iônica próxima de zero entre metais alcalinos e cálcio, juntamente com a elevada relação $\left[\mathrm{HCO}_{3}^{-} / \mathrm{SiO}_{2}\right]$ (Tab. 3), indicam que a dissolução dos minerais carbonáticos é a principal fonte de cálcio para a água subterrânea. Esta ainda apresenta concentrações relativamente elevadas de bário $(0,43 \mathrm{mg} / \mathrm{L})$, provavelmente ligadas à dissolução de barita em veios da rocha encaixante.

As águas associadas ao Maciço Alcalino de Poços de Caldas (Grupo 11, Águas da Prata - SP) percolam foiaítos, fonólitos e tinguaítos, com mineralogia de anortoclásio, sanidina e nefelina (feldspatóides) e egirina (piroxênio), ricos em metais alcalinos $(\mathrm{Na}$ e $\mathrm{K})$ e com baixa relação de sílica/alumínio (Cruz \& Peixoto, 1991). Por isso, ocorre forte predomínio de bicarbonato e de sódio na água, embora também haja concentrações notáveis de sulfato, cálcio e magnésio (Tab. 2). Dentre os minerais acessórios que contribuem para a mineralização da água, os mais importantes são a pirita (que contribui para o aumento das concentrações de sulfato e diminuição do $\mathrm{pH}$ que, embora neutro, encontra-se relativamente baixo para o contexto hidrogeoquímico) e a fluorita (que contribui para as concentrações relativamente elevadas de fluoreto na água $-1,59 \mathrm{mg} / \mathrm{L}$ ). As águas deste Maciço apresentam as maiores mineralizações (RS=633 $\mathrm{mg} / \mathrm{L}$ ) dentre todas as envasadas no Brasil. A tabela 3 indica que a calcita e dolomita encontram-se em equilíbrio químico nesta água, e que a elevada relação $\left[\mathrm{HCO}_{3}^{-} / \mathrm{SiO}_{2}\right]$ e a baixa relação $\left[\mathrm{SiO}_{2} /\right.$ $\mathrm{Na}$ ] são coerentes com o fato dos minerais das rochas alcalinas apresentarem menores quantidades de sílica e de serem mais susceptíveis ao intemperismo que os aluminossilicatos predominantes das rochas granito-gnáissicas. Os gráficos da figura 6 indicam que as montmorilonitas e o feldspato potássico são os minerais mais estáveis. Todas estas características são indicativas de que a água é proveniente de aqǘf́reros profundos e de elevado tempo de trânsito.
Arenitos do Sistema Aqüífero Guarani As formações Pirambóia e Botucatu compõem a mais importante unidade aqüífera da Bacia do Paraná, o Sistema Aqüífero Guarani. A Formação Botucatu é composta essencialmente por arenitos quartzosos maturos textural e mineralogicamente, devido ao trabalho da ação eólica em ambiente desértico. A Formação Pirambóia é de origem flúvio-lacustre e eólica e os sedimentos menos maturos (Caetano-Chang \& Wu 1992). Sobre estas formações, ocorrem os basaltos da Formação Serra Geral que confinam o sistema em aproximadamente $90 \%$ de sua área. Dadas as dimensões continentais deste sistema, ocorre uma intensa modificação da composição química da água desde a área de recarga até as porções mais fortemente confinadas (Sracek \& Hirata 2002).

As análises disponíveis das águas minerais do Sistema Aqüífero Guarani são provenientes da zona de recarga regional. Estas águas (Grupo 20) são bicarbonatadas predominantemente cálcicas, apresentam $\mathrm{pH}$ ligeiramente ácido e RS baixo (Figs. 4 e 5G). As relações iônicas indicam predomínio dos processos da geoquímica de silicatos, sem a influência de carbonatos, sulfatos e contribuição marinha (Tab. 3). As porções mais confinadas e a jusante do aqüífero exibem águas que alcançam concentrações de sólidos dissolvidos da ordem de $250 \mathrm{mg} / \mathrm{L}, \mathrm{pH}$ fortemente básico $(>9,0)$, bicarbonato e sódio como íons predominantes e minerais carbonáticos supersaturados (Sracek \& Hirata 2002). O modelo de evolução hidrogeoquímica, da área de recarga para a porção fortemente confinada do aqüífero, corresponde a alguma dissolução de carbonatos e de evaporitos associada com a troca catiônica do sódio pelo cálcio na matriz aqüífera (Sracek \& Hirata 2002).

Rochas basálticas Os derrames basálticos de natureza toleítica da Formação Serra Geral (IPT 1981) compõem outro grupo de interesse geoquímico. A figura $5 \mathrm{H}$ exibe dois grupos de águas provenientes desta unidade, associadas à profundidade de ocorrência das fontes. As águas do Grupo 21 são de natureza bicarbonatada-cálcica, ligeiramente sódica e magnesiana, $\mathrm{pH} \approx 7,0$ e com variação significativa de RS e cálcio (Fig. 4), representativas, portanto, de fluxos rasos e profundos $(<150 \mathrm{~m})$. As relações iônicas confirmam existir o predomínio da geoquímica de alteração intempérica de silicatos, sendo que a relação $\mathrm{Na} / \mathrm{Ca}$ sinaliza para a existência de intemperismo de plagioclásio cálcico, concordante com a mineralogia essencial dos basaltos (plagioclásio cálcico e piroxênio do tipo augita). A caulinita é o argilomineral mais estável neste ambiente geoquímico (Fig. 6).

O Grupo 22 representa as águas de circulação ainda mais profundas e caracterizam-se por serem fortemente bicarbonatadas sódicas, com cálcio e magnésio praticamente ausentes, com $\mathrm{pH}>9,0$ e RS $\approx 250 \mathrm{mg} / \mathrm{L}$ (Tab. 2 e Fig. 5H). Nestas condições, a calcita encontrase supersaturada e as relações $[\mathrm{Na} / \mathrm{Cl}]$ e $[\mathrm{Si} / \mathrm{Na}]$ indicam haver outra fonte de sódio além daquelas provenientes de contribuição marinha ou de intemperismo de albita (Tab. 3). Os diagramas da figura 6 indicam, inclusive, que a água de Ibirá (SP), exemplo deste grupo de águas, 
encontra-se próxima do campo de estabilidade da albita. As características destas águas são semelhantes às características das águas do Sistema Aqüífero Guarani confinado, o que sinaliza para a possibilidade de contribuição de águas ascendentes deste aqüífero.

INFLUÊNCIA ANTRÓPICA NA COMPOSIÇÃO HIDROQUÍMICA Identificou-se a influência humana como fator de mudança da composição química original da água mineral. A principal espécie que denuncia alteração de origem antrópica na qualidade da água é o nitrato. Concentrações elevadas de nitrato na água subterrânea denotam a ocorrência de contaminação advinda de águas servidas, principalmente em ambiente urbano, e por utilização de fertilizantes inorgânicos e orgânicos, em ambiente rural.

$\mathrm{O}$ nitrato ocorre naturalmente apenas em pequenas concentrações, principalmente em áreas densamente florestadas. Mueller \& Helsel (1996) definiram um background máximo de $9 \mathrm{mg} / \mathrm{L}$ de nitrato em águas de regiões de florestas nos Estados Unidos, indicando que concentrações acima deste background certamente significam existência de impacto de origem antrópica. Cagnon \& Hirata (2004), por outro lado, estudando o impacto do nitrato nas águas subterrâneas do Sistema Aqüífero Bauru na área urbana do município de Urânia (SP), definiram que concentrações de nitrato acima de 3 $\mathrm{mg} / \mathrm{L}$ significavam contaminação de origem antrópica e que valores entre 1 e $3 \mathrm{mg} / \mathrm{L}$ poderiam ainda significar impacto, a ser confirmado mediante um estudo de uso do solo na área de contribuição dos poços.

Verificou-se que $8 \%$ da população de marcas de água mineral ( 25 dentre 303 do total) apresenta concentrações de nitrato acima de $9 \mathrm{mg} / \mathrm{L}$, certamente significando alteração da qualidade original da água por atividade antrópica (Tab. 5). Quando a concentração de $3 \mathrm{mg} / \mathrm{L}$ é considerada, tem-se que $25 \%$ das marcas de água mineral apresentam nitrato acima deste limite, sinalizando para a possibilidade de alguma alteração. Algumas marcas apresentam concentrações muito próximas do limite de potabilidade $(50 \mathrm{mg} / \mathrm{L}$ - Brasil 2005 - Resolução RDC 274).

Concentrações elevadas de cloreto e nitrato associam-se em algumas situações (Tab. 5), indicando a ocorrência de contaminação originada por infiltração de esgotos. Exemplos desta situação são as águas de uma área fortemente urbanizada na cidade de São Paulo. Análises de uma determinada marca de água mineral datadas de 1992 e 2002 sinalizam uma elevação nas concentrações de nitrato (de 4,50 para $18,40 \mathrm{mg} / \mathrm{L}$ ) e de cloreto $(6,81$ para $14,34 \mathrm{mg} / \mathrm{L})$ no período. A concentração background de cloreto na água subterrânea da Bacia de São Paulo não é maior que $1,0 \mathrm{mg} / \mathrm{L}$ (Tab. 2 - Grupo 17).

As águas impactadas por nitrato geralmente possuem $\mathrm{pH}$ ácido (Tab. 5), indicando que a maior parte dos aqüíferos impactados por nitrato são de circulação rasa e que, portanto, já eram anteriormente vulneráveis à contaminação. $\mathrm{O}$ contexto geológico das captações parece não exercer controle sobre a ocorrência de ni- trato na água, já que é comum a ocorrência desta espécie em aqüíferos sedimentares e fraturados. Portanto, a ocorrência de nitrato na água mineral parece se dever mais à proximidade da fonte de contaminação do que a contextos hidrogeológicos específicos.

Uma vez que cerca de $1 / 3$ das águas minerais brasileiras não impactadas são provenientes de aqüíferos de elevada vulnerabilidade natural à contaminação, julga-se imprescindível a aplicação do instrumento de definição de perímetros de proteção das fontes, além de monitoramento contínuo, a fim de preservar a qualidade destas águas.

De acordo com a Legislação de Águas Minerais, a água subterrânea no Brasil é classificada como "mineral" no caso desta possuir determinadas características químicas e propriedades medicamentosas. Esta mesma Legislação considera que águas com concentrações de nitrato de até $50 \mathrm{mg} / \mathrm{L}$ são potáveis. No entanto, demonstrou-se acima que tais concentrações indicam contaminação antrópica. Sendo assim, tal como discutido em Bertolo (2006), suas propriedades medicamentosas e, conseqüentemente, sua classificação como "água mineral" tornam-se claramente questionáveis.

CONCLUSÕES Este trabalho apresenta um panorama geral das características hidrogeoquímicas da água mineral envasada brasileira. Grande parte destas águas provém de aqüíferos rasos, de fluxos locais e de rápido tempo de trânsito, percolando material já intemperizado, resultando em águas de baixa mineralização e de $\mathrm{pH}$ ácido. As águas de regiões litorâneas são marcadamente do tipo cloretada sódica, influência direta de entradas de componentes da água do mar trazidos pela atmosfera. As águas da região centro-sul do Brasil são mais influenciadas pelo tipo de rocha percolada e pela profundidade de captação da água, sendo raras, entretanto, ocorrências de águas com resíduo seco maior que $200 \mathrm{mg} / \mathrm{L}$.

Cerca de 1/4 da população de análises considerada apresenta sinais de alteração da qualidade natural da água mineral, notadamente por conta da detecção de concentrações de nitrato variando de 3 a $49 \mathrm{mg} / \mathrm{L}$. Embora sejam consideradas potáveis, tais alterações estão associadas com a recarga de águas impactadas por efluentes domésticos e/ou fertilizantes inorgânicos e orgânicos.

As características de baixa mineralização e de baixo $\mathrm{pH}$ da maior parte das águas minerais do Brasil definem aqüíferos de elevada vulnerabilidade natural à contaminação. Por isso, estudos de perímetro de proteção de obras de captação devem ser aplicados, de modo a prevenir contaminações futuras, principalmente para os empreendimentos contendo águas com estas características químicas. Um estudo detalhado do uso e ocupação de solo deve ser realizado na zona de contribuição da captação, e um monitoramento periódico deve ser aplicado para aqueles casos onde houver identificação de possíveis fontes de contaminação de origem antrópica sobre a zona de contribuição. 
Agradecimentos Agradecemos às várias pessoas que gentilmente contribuíram para este trabalho, em especial a Sibele Ezaki, Cláudia Ohnuma, Cássio Gui- marães, Rhauna Damous e Kátia Melitto, além do Dr. Rômulo S. Angélica e um relator anônimo, que gentilmente realizaram a revisão do artigo.

\section{Referências}

Bertolo R.A. 2006. Reflexões sobre a classificação e as características químicas da água mineral envasada do Brasil. In: Congresso Brasileiro de Águas Subterrâneas, 14, Curitiba, Atas, CD, 18 p.

BRASIL. 2005. Resolução RDC ANVISA/MS n'. 274, de 22 de setembro de 2005. Regulamento Técnico para Águas Envasadas e Gelo. Diário Oficial da União, Brasília, DF, 22 set. 2005.

Caetano-Chang M.R. \& Wu F.T. 1992. Bacia do Paraná: Formações Pirambóia e Botucatu. In: SBG, Congresso Brasileiro de Geologia, 37, São Paulo, Roteiro de Excursão, $19 p$.

Cagnon F. \& Hirata R. 2004. Source of nitrate in the groundwater of Adamantina aquifer in Urânia, SP - Brazil. In: International Association of Hydrogeologists, IAH Congress, 33 / ALHSUD, 7, Zacatecas, México, atas, CD.

Calmbach L. 1995. Hydrowin software. Version 3.0. Institut de Minéralogie BFSH2. 1015 Lausanne, Suisse.

Campos H.C.N.S. 1993. Caracterização e cartografia das províncias hidrogeoquímicas do Estado de São Paulo. Tese de Doutoramento, Instituto de Geociências, Universidade de São Paulo, 177 p.

Cavalcante I. N. 1998. Fundamentos hidrogeológicos para a gestão integrada de recursos hídricos na Região Metropolitana de Fortaleza, Estado do Ceará. Tese de Doutoramento, Instituto de Geociências, Universidade de São Paulo, 150p.

Cruz W.B., Peixoto C.A.M. 1991. A Evolução Química das Águas Subterrâneas de Poços de Caldas - MG. Revista Brasileira de Geociências, 21(1):23-33.

DNPM Departamento Nacional da Produção Mineral; CPRM Companhia de Pesquisa de Recursos Minerais. 1983. Mapa Hidrogeológico do Brasil. Brasília, Escala 1:5.000.000.

DNPM Departamento Nacional da Produção Mineral. 2005. Sistema SIGHIDRO - Banco de dados de fontes de águas minerais. Disponível em: $h t t p: / / w w w . d n p m . g o v . b r /$ webhidro/Pesquisa.asp. Acessado em novembro/2005.

Freeze R.A. \& Cherry J.A. 1979. Groundwater. PrenticeHall, 604p.

Gutierrez A. \& Hirata R. 2004. Modelo hidrogeoquímico do aqüífero Adamantina em Urânia (São Paulo). IN: International Association of Hydrogeologists, IAH Congress, 33 / ALHSUD, 7, Zacatecas, México, Atas, CD.

Hounslow A.W. 1995. Water Quality Data. Analysis and In- terpretation. Lewis Publishers, $397 \mathrm{p}$.

IBGE Instituto Brasileiro de Geografia e Estatística 2002. Mapa de Climas do Brasil. Escala 1:5.000.000.

IPT Instituto de Pesquisas Tecnológicas. 1981. Mapa Geológico do Estado de São Paulo. Esc. 1:500.000.

Martins A.M., Mansur K.L., Erthal F.L.C., Maurício R.C., Pereira Filho J.C., Caetano L.C. 2002. Águas Minerais do Estado do Rio de Janeiro. Rio de Janeiro, Departamento de Recursos Minerais DRM-RJ, Secretaria de Estado de Energia da Indústria Naval e do Petróleo, 121 p.

Martins, A. M.; Mansur, K. L.; Erthal, F.L.C.; Maurício, R.C.; Pereira Filho, J.C.; Caetano, L.C. 2002. Águas Minerais do Estado do Rio de Janeiro. Departamento de Recursos Minerais DRM-RJ, Secretaria de Estado de Energia da Indústria Naval e do Petróleo. Rio de Janeiro, $121 \mathrm{p}$.

Mineropar. 1986. Mapa Geológico do Estado do Paraná. Escala 1:400.000.

Mueller D.K. \& Helsel D.R. 1996. Nutrients in the Nation's Waters - Too much of a good thing? - U.S. Geological Survey Circular 1136. Disponível em: http://water.usgs. gov/nawqa/circ-1136/circ-1136main.htm. Acessado em junho/2005.

Queiroz E.T. 2004. Diagnóstico das Águas Minerais e Potáveis de Mesa do Brasil. In: Congresso Brasileiro de Águas Subterrâneas, 12, Cuiabá, Atas, CD, 26p.

Sracek O \& Hirata R.C.A. 2002. Geochemical and stable isotopic evolution of the Guarani Aquifer System in the state of São Paulo, Brazil. Hydrogeology Journal, 10:643-655.

Szikszay M. 1993. Geoquímica das Águas. São Paulo, Boletim IGUSP, Série didática n 5 , IG-USP, 166p.

Torres M.G., Gaspar J.C. 1995. Geoquímica do Manto de Intemperismo da Mina de Fosfato do Complexo AlcalinoCarbonatítico do Barreiro - Araxá-M.G. In: Congresso Brasileiro de Geoquímica, 5 e Congresso de Geoquímica dos Países de Língua Portuguesa, 3, Niterói/RJ, Resumo expandido, $3 \mathrm{p}$.

van Dorr J. 1969. Physiographic, stratigraphic and structural development of the Quadrilátero Ferrifero, Minas Gerais, Brazil. USGS Professional Paper n. 641. 110 p.

Manuscrito A-1647 Aceito em 22 de agosto de 2007 